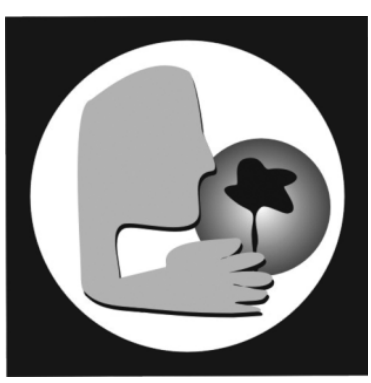

Sustentabilidade e $\mathrm{m}$ Debate

\title{
Visões Políticas de um Desafio Global
}

\author{
Thiago de Araújo Mendes ${ }^{1}$
}

${ }^{1}$ Centro de Desenvolvimento Sustentável, Universidade de Brasília. Brasília, Distrito Federal, Brasil. Doutorando do Programa de Pósgraduação em Desenvolvimento Sustentável. E-mail: thiagomendes81@yahoo.com.br

Recebido em 12.09.2010

Aceito em 25.11.2010

\section{RESENHA}

GIDDENS, Anthony. A política da mudança climática. Rio de Janeiro: Zahar, 2010. 316p. ISBN: 978-85-378-0261-8. [Traduzido do original: GIDDENS, Anthony. The politics of climate change. Cambridge: Polity Press, 2009]. Tradução de Vera Ribeiro. Revisão técnica: André Piani.

O professor Anthony Giddens é autor de mais de 34 livros e 200 artigos científicos, traduzidos para cerca de 40 línguas. Giddens é professor emérito da London School of Economics (LSE), onde desempenhou o papel de diretor (1997 a 2003). De origem modesta (classe média baixa inglesa), Giddens foi o primeiro membro de sua família a freqüentar uma universidade e é considerado atualmente o quinto autor mais citado na área de Humanidades. Em 2004 foi nomeado Barão de Southgate na London Borough of Enfield, quando atuou como conselheiro do governo trabalhista de Tony Blair (Primeiro-Ministro do Reino Unido da Grã-Bretanha e Irlanda do Norte de 1997 a 2007). Entre seus livros mais influentes estão The Constitution of Society (1984), Modernity and Self-Identity (1991),
Beyond Left and Right (1994) and The Third Way (1998). Atual membro da Câmara dos Lordes, Giddens atua como consultor de vários governantes ao redor do globo.

A política da mudança climática é o primeiro texto científico de maior fôlego produzido pelo autor adotando a mudança global de clima como recorte de pesquisa. A publicação resulta do envolvimento de Giddens em um projeto de pesquisa conjunto do think tank internacional Policy Network e do centro de estudos Global Governance da LSE. Apesar de conter elementos teórico-explicativos de disciplinas diversas, esta obra pode ser considerada essencialmente como um livro abrigado nos limites disciplinares das ciências humanas, mais especificamente no campo da Ciência Política. Portanto, como 


\section{Sustentabilidade em Debate}

destaca o próprio autor, "este não é um livro sobre a mudança climática, mas sobre a política da mudança climática" (p. 36).

Giddens procura analisar os principais processos da política mundial e as suas inter-relações com a formulação de políticas públicas nacionais voltadas para lidar com a problemática da mudança do clima. Entretanto, ele concentra a maior parte de seu esforço na análise dos países industrializados, pois "foram estes que jogaram na atmosfera a maioria das emissões (...) e cabe a eles assumir a responsabilidade primordial por controlá-las no futuro imediato" (p. 22). Por conseguinte, o autor sinaliza que esses países deveriam assumir a vanguarda das reduções de emissões e das reformas sociais necessárias para o estabelecimento de uma nova economia de baixo carbono.

Ao longo de nove capítulos, Giddens adota uma linguagem direta e acessível a leitores que se interessem pelo tema de mudança do clima e política, mesmo não sendo estas suas áreas de maior intimidade. $\mathrm{O}$ texto se constitui em um esforço para articular avaliações sóbrias sobre a difundida abordagem catastrofista da mudança climática (gerenciamento de risco e perigo), ponderações pragmáticas e opiniões polêmicas sobre propostas políticas (ex. papel da conservação da natureza e do comércio de emissões), permeadas por análises sobre práticas individuais cotidianas. Os resultados encontrados são frutos da garimpagem de uma bibliografia de mais 240 títulos, que incluem desde publicações científicas, planos governamentais, papers de origem empresarial e não governamental a até artigos jornalísticos e estudos de organismos multilaterais.

O mérito científico da obra encontra-se na junção de formulações teóricas clássicas (abordagem realista das relações internacionais e geopolítica) com as noções inovadoras específicas para o tratamento da questão da política da mudança climática. Para o autor, a problemática do aquecimento global tem natureza diferente de qualquer outro problema político, seja por sua dimensão de futuro, seja por sua escala. A partir daí, é inevitável que a política da mudança do clima lide com o "paradoxo de Giddens". Ele pode ser assim resumido: mesmo que as ameaças e perigos sejam conhecidos, eles não são imediatos e palpáveis no decorrer da vida cotidiana e, assim, pouco de concreto é feito a seu respeito. Porém, "esperar que eles se tornem visíveis e agudos para só então tomarmos medidas sérias será por definição, tarde demais" (p. 20). Por conseguinte, Giddens, ao adotar a noção de que a questão não é de fato "salvar o planeta" (até por que a vida no planeta sobreviverá independente dos seres humanos), vê o problema como um enorme desafio, mas também como uma incrível oportunidade para preservar e aprimorar um estilo de vida digno para os seres humanos em harmonia com a Terra.

Ao constatar que "não temos nenhuma política referente à mudança climática" (p. 22) Giddens combina as suas análises com proposições normativas de possíveis estratégias políticas para enfrentar a problemática do aquecimento global. Dentre inúmeras formulações, destaca-se a defesa da importância do papel do Esta$d o$, especialmente como "assegurador" de processos de convergência política e econômica no intuito de apoiar e estimular os agentes sociais a adotar as medidas necessárias para a solução generalizada do problema. Outra formulação de peso é sobre a defesa do planejamento, devido à perspectiva de longo prazo exigida por este desafio global. Apesar de reconhecer a importância do movimento ambientalista, ao qual dedica um capítulo específico, Giddens aponta limites 
para o discurso verde e sinaliza que a abordagem conservacionista pode inclusive prejudicar os esforços de definição de medidas políticas de combate ao aquecimento global. De maneira similar, o autor aponta as limitações sobre o resultado do comércio de emissões para mitigação das causas do problema e dá sentido mais amplo ao papel dos mercados na construção de soluções concretas. Essas soluções estariam vinculadas as mudanças de padrões de produção e consumo via processos de estímulo à inovação, à difusão e à transferência de tecnologia. Conseqüentemente, o autor defende mecanismos alternativos e adicionais de tributação e taxação.

A política de adaptação também mereceu destaque (capítulo 7 e inserções substanciais no capítulo 9), considerando definições de vulnerabilidades em países pobres e industrializados. Assim como nas proposições de medidas de mitigação, o princípio poluidor-pagador deve ser pedra fundamental para cobrir os custos dos mecanismos de adaptação, incluindo seguros e estratégias para tratar perdas e danos, que necessariamente deverão ser honradas em sua maior parcela pelos países desenvolvidos. Giddens explicita ainda as inter-relações e motivações geopolíticas que ficam obscuras nas análises da negociação internacional de mudança climática. $\mathrm{O}$ autor defende que o debate sobre segurança energética, controle do acesso a recursos naturais pelas grandes potências, inovação tecnológica e o imperativo ao desenvolvimento serão temas indissociáveis dos processos de solução do desafio global da mudança do clima. Apesar de ressaltar a importância do papel da União Européia para a construção de uma solução global, Giddens aponta a sua limitada disposição de assumir um posicionamento coerente e uníssono no continente, além de ainda ter sérios problemas energéticos, que envolvem uma relação delicada com a Rússia.
Ao comparar como os grandes países em desenvolvimento enfrentam as questões da mudança do clima, o autor cita a posição do Brasil, em especial devido ao seu papel de vanguarda na negociação internacional, ao colocar os desafios para sustentabilidade dos biocombustíveis e a relevância dos seus novos estoques de petróleo para o debate sobre segurança energética. Giddens aponta que as políticas brasileiras nas áreas de combate ao desmatamento e de energia renovável são dignas de apoio internacional e de replicação no mundo em desenvolvimento.

Entretanto, o autor deixa evidente que boa parte da solução necessariamente terá que surgir do binômio EUA-China (os principais consumidores individuais de carvão mineral da atualidade). "Estados Unidos e a China têm a capacidade de ratificar ou destruir as nossas chances de sucesso" (p. 277). Após confirmar o realismo político como mainstream das relações internacionais atuais, Giddens faz uma defesa de um multilateralismo da maioria para alcançarmos soluções consistentes globalmente. Em seu desfecho, ele indica que a mudança do clima pode se tornar tanto um retorno à "Idade das Trevas" quanto uma abertura para uma "nova era do Iluminismo", porém Giddens aposta que o futuro provavelmente será uma mescla destes dois caminhos.

Enfim, recomenda-se leitura da obra para membros da academia, que lidam diretamente com área temática de mudança do clima e sustentabilidade, assim como para cientistas sociais e políticos que se debruçam sobre os problemas de formulação de políticas públicas e estratégias de energia, desenvolvimento e geopolítica. Da mesma forma, a leitura é indicada para gestores governamentais e não governamentais e para jornalistas especializados em cadernos de ciência, economia e meio ambiente. 


\section{Referências}

GIDDENS, Anthony. The Constitution of Society: Outline of the Theory of Structuration. Cambridge: Polity Press, 1984.

GIDDENS, Anthony. Modernity and SelfIdentity: Self and Society in the Late Modern Age. Cambridge: Polity Press, 1991.

GIDDENS, Anthony. Beyond Left and Right: the future of radical politics. Cambridge: Polity Press, 1994.

GIDDENS, Anthony. The Third Way: The Renewal of Social Democracy. Cambridge: Polity Press, 1998. 